\title{
COMPARISON OF CONDUIT VOLUMES OBTAINED FROM DIRECT MEASUREMENTS AND ARTIFICIAL TRACER TESTS
}

\author{
Anna Vojtechoviska', Jiri Bruthans', and Frantisek Krejca²
}

\begin{abstract}
An isolated phreatic loop in a natural cave was used to test the reliability of artificial-tracer tests for estimating the volume of a flooded karst conduit. The volume of a phreatic tube was measured by filling a drained phreatic loop with a constant inflow over a known time period. The volume of the phreatic loop is $190 \pm 20 \mathrm{~m}^{3}$, and it was compared to independent calculations of conduit volumes based on values based on tracer breakthrough curves. The best results were for mean transit time, where tracer-test calculations yielded volumes very similar to the volume obtained by direct filling of the loop. On the other hand, using the first-arrival time or peak time in the volume calculation resulted in considerable underestimation of the phreatic tube's volume, and these methods should be avoided except when breakthrough curves are affected by molecular diffusion. This demonstrates that volume estimation by tracer tests may be quite precise for common natural conduits, but results are strongly affected by the breakthrough-curve parameter chosen by the experimenter.
\end{abstract}

\section{INTRODUCTION}

Karst conduits are the primary drains of karst aquifers and act as fast groundwater-flow paths (Atkinson, 1977). Thus, understanding the hydrodynamic character of such conduits is important for understanding groundwater flow and hydraulic response propagation and for protection of groundwater sources in karst areas.

Quantitative tracer tests are typically used to estimate the basic characteristics of flooded karst conduits (Atkinson et al., 1973; Käss, 1998; Field, 2002; Goldscheider et al., 2008). Test results are used to approximate karst conduit volumes and mean cross-section areas (only the water-filled part of conduits is considered here). Such test results, especially if obtained for various flow rates, help to distinguish phreatic conduits (i.e., sumps) from vadose streams and are useful for estimating the static volume of conduits (Goldscheider et al., 2008). The maximum discharge and mean cross-sectional area of a conduit are used to estimate mean flow velocity at peak discharge. The velocities, combined with conduit geometries, are useful for studies of sediment-transport processes (Bruthans and Zeman, 2003). Moreover, the mean cross-sectional area is an important indicator for determining if sumps are large enough for divers to explore. Many different trace times are used to calculate conduit volumes (see below). But, unlike the case of artificial tubing, it is hard to test the reliability of volume estimates for natural karst conduits.

The purpose of this study was to compare the volume of a cave loop calculated from a tracer test with the volume measured by actually filling an empty sump. The study area is in Chýnov Cave, located $100 \mathrm{~km}$ south of Prague, Czech Republic, where it was possible to completely empty an isolated phreatic loop (sump) by pumping away the water.

\section{Conduit Description}

Chýnov Cave is situated in a thin layer of calcite-pure metamorphosed limestone. The cave contains an array of deep-phreatic conduits (sensu Ford and Ewers, 1978) and is traversed by a small stream with discharge varying between 6 and $13 \mathrm{~L} \mathrm{~s}^{-1}$. We studied the Kaskady phreatic loop, which is a single underwater passage with a length of about $105 \mathrm{~m}$ and a maximum water depth of $11 \mathrm{~m}$ (Fig. 1). Crosssections are variable (Fig. 1). Walls are undulating but not covered by scallops. The absence of scallops is attributed to predominantly slow flow rates. On the conduit's bottom there is about $30 \mathrm{~m}^{3}$ of detritus and insoluble materials with particles diameters up to several tens of centimeters. Upstream and downstream of the phreatic loop the flow rates of the underground stream are similar, and no underwater inflows were observed on complete draining of the loop during a pumping test. Therefore, we consider the phreatic loop isolated from any significant water-filled fractures or matrix porosity, which would have yielded water into the emptied loop.

\section{Methods}

The flow-rate through the loop was measured by timing the filling of a $50 \mathrm{~L}$ vessel. A tracer $(\mathrm{NaCl})$ was injected directly into a stream cascade located at point IP (Fig. 1) to ensure good mixing of the tracer. $\mathrm{A} \mathrm{NaCl}$ breakthrough curve was determined using electrical-conductivity measurement of the underground stream at SP (Fig. 1).

\footnotetext{
${ }^{1}$ Department of Hydrogeology, Engineering Geology, and Applied Geophysics, Faculty of Sciences, Charles University in Prague, Albertov 6, 12843 Prague, Czech Republic,bruthans@natur.cuni.cz

${ }^{2}$ Management of Chýnov Cave, Dolní Hořice 54, 39155 Chýnov, Czech Republic
} 


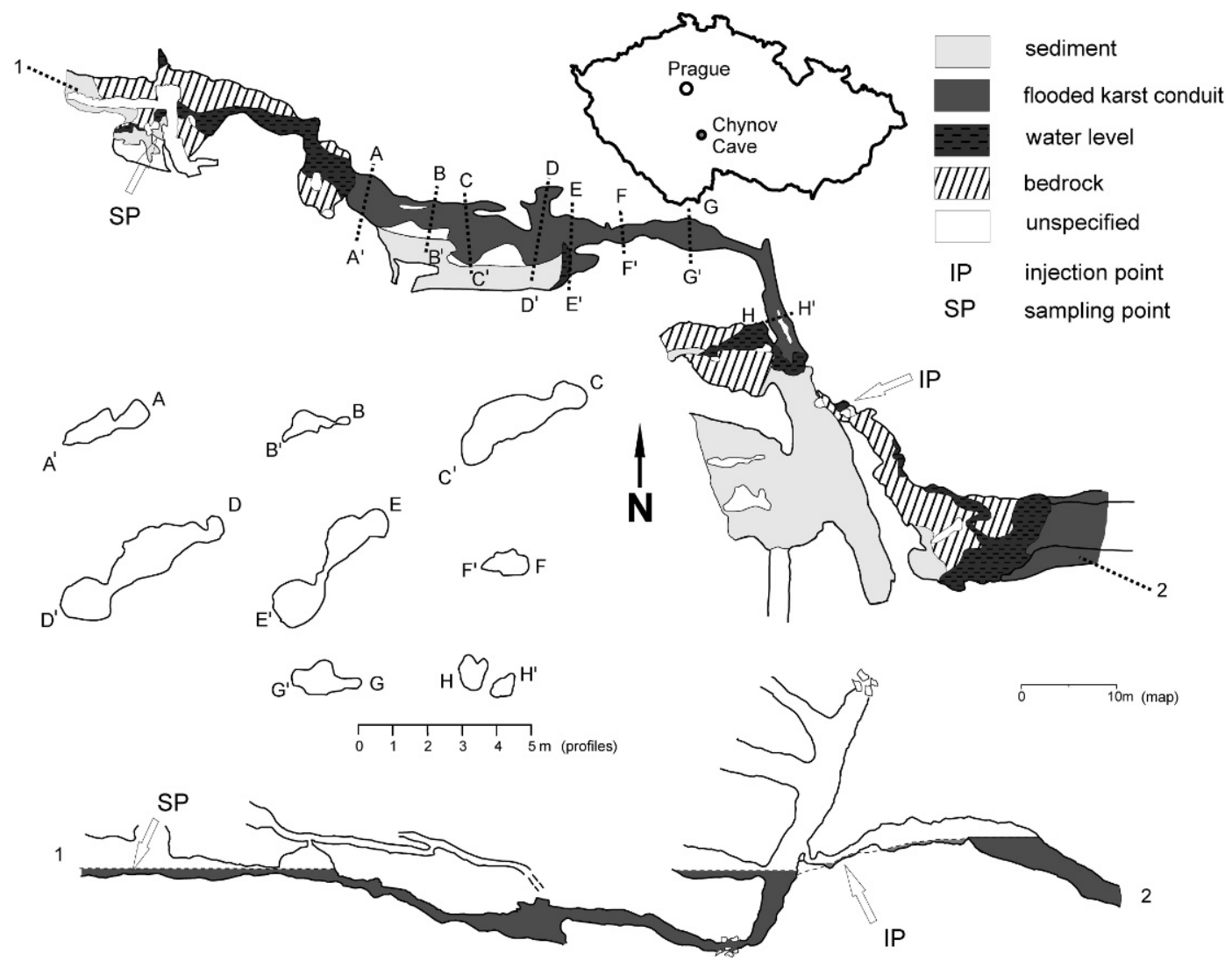

Figure 1. Map and projected vertical section of sump in Chýnov Cave $\left(49^{\circ} 25^{\prime} 47.317^{\prime \prime} \mathrm{N}, 14^{\circ} 49^{\prime} 57.576^{\prime \prime} \mathrm{E}\right)$. Locations of injection of tracer (IP) and sampling point (SP) are indicated.

Measurements were made at one-minute intervals by a Cond 340i (WTW Co.) device equipped with a data logger. After the sodium chloride content decreased considerably from peak values (360 minutes after injection), the logging interval was changed to five minutes. The tracer test was monitored for 23 hours. Because conductivity is dependent on temperature, the water temperature was monitored as well. The temperature was stable during the tracer test $\left(8.7^{\circ} \mathrm{C}\right)$. In addition to logging conductivity, we collected water samples for analysis of $\mathrm{Cl}^{-}$by argentometric titration. The relationship between the conductivity and measured the $\mathrm{Cl}^{-}$ content was linear $\left(R^{2}=0.999\right)$ with a positive correlation between conductivity and the $\mathrm{NaCl}$ content in the water. The computer program Qtracer2 (Field and Nash, 1997; Field, 2002) was used to analyze the breakthrough curve, and the conduit volume was calculated as $V=Q \times t$, where $Q$ is the stream flow rate or discharge $\left(\mathrm{L} \mathrm{s}^{-1}\right)$ and $t$ is time (s). It was possible to use a variety of times taken from the breakthrough curve, and we tested many of these (Fig. 2, Table 1).

After the tracer test, the water in the isolated phreatic loop was pumped out completely, and the phreatic loop was surveyed and documented (Fig. 1). The loop was allowed to refill, and the volume of the phreatic loop was calculated as $V_{F}=Q_{F} \times t_{F}$, where $t_{F}$ is the time needed to fill the drained phreatic loop by inflowing water and $Q_{F}$ is the measured inflow.

\section{RESUlts AND Discussion}

The volume of phreatic loop measured by refilling was $190 \mathrm{~m}^{3}$ with an estimated error of $\pm 20 \mathrm{~m}^{3}$ ) due to a $10 \%$ uncertainty in discharge. The measured breakthrough curve of the tracer test is depicted in Figure 3. The tracer arrived 116 minutes after injection and reached its maximum concentration 176 minutes after the injection. A relatively long tail was observed (Fig. 3). Tracer times are summarized in Table 1 . We recovered $92 \%$ of the tracer mass, which shows that part of the tracer was apparently lost. If this was not just due to an error in discharge estimation, it might have been caused by a very long tail below our detection limit due to diffusion into the static water trapped in the detritus on the bottom of the sump.

Comparing the karst conduit's refilling volume $\left(V_{F}\right)$ with calculations of conduit volumes based on timing of the tracer-breakthrough curve, the best breakthrough curve estimates are based on mean transit time, both centroid and half-recovery (Table 1). On the other hand, using first arrival time or peak time in volume calculation

Journal of Cave and Karst Studies, December 2010 •157 


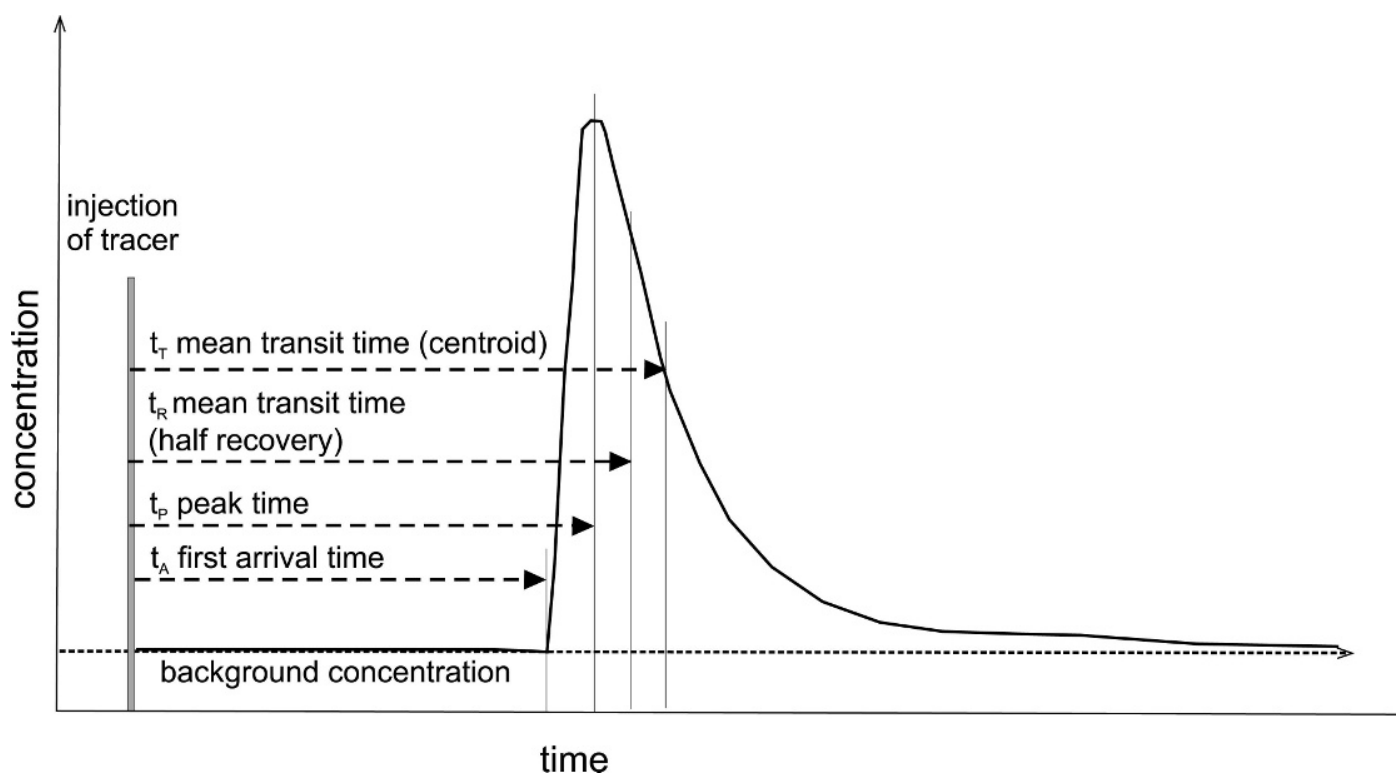

Figure 2. Definition of various times used in this paper for a hypothetical breakthrough curve. First arrival time is defined by raising the concentration of tracer well above the background. Peak time is defined by maximum concentration of the tracer. Mean transit time (half recovery) is defined by passage of $\mathbf{5 0 \%}$ of tracer mass (background is subtracted). Mean transit time (centroid) is defined by centroid of the tracer (background is subtracted).

resulted in considerable underestimation of the conduit volume.

When the discharge from cave opening is constant, $V=Q$ $\times t$ can be used to calculate its volume (Atkinson et al., 1973; Field and Nash, 1997). Estimates of cave volumes from tracer-test data have relied on various definitions of $t$. Atkinson et al. (1973), who assumed that water moves through the system like piston in a cylinder, used the peak time. Smart (1988), Field and Nash (1997), and Goldscheider et al. (2008) used the mean tracer transit time. The centroid generally lags behind the peak concentration of the tracer mass of the tracer-breakthrough curve (Fig. 2). On the other hand, Birk et al. (2004) used the first arrival or peak times as better measures of the conduit geometry than the mean tracer transit time because their calculation of conduit volumes was based on the assumption of plug flow conditions.

Thrailkill et al. (1991) suggests that average velocity is probably best calculated from the centroid of the breakthrough curve (mean transit time). However, because of the skew of the breakthrough curve, the position of the

Table 1. Times and corresponding calculated volumes of flooded parts of phreatic loop in Chýnov Cave. For explanation see the text and Figure 2.

\begin{tabular}{|c|c|c|c|}
\hline Time & $\begin{array}{l}\text { Minutes after } \\
\text { Injection }\end{array}$ & $\begin{array}{l}\text { Corresponding } \\
\text { Volume }\left(\mathrm{m}^{3}\right)\end{array}$ & $\begin{array}{c}\text { Comparison with True } \\
\text { Volume }(\%)\end{array}$ \\
\hline Real volume (pumping) & NA & 190 & 100 \\
\hline $\mathrm{t}_{\mathrm{A}}=$ first arrival time & 116 & 85 & 45 \\
\hline $\mathrm{t}_{\mathrm{P}}=$ peak time & 176 & 129 & 68 \\
\hline $\begin{array}{l}\mathrm{t}_{\mathrm{R} 1}=\text { mean transit time } \\
\text { (recovery } 46 \% \text { of injected } \\
\text { tracer; } 50 \% \text { of recovered } \\
\text { tracer) }\end{array}$ & 231 & 169 & 89 \\
\hline $\begin{array}{l}\mathrm{t}_{\mathrm{R} 2}=\text { mean transit time } \\
\text { (recovery } 50 \% \text { of injected } \\
\text { tracer) }\end{array}$ & 242 & 177 & 93 \\
\hline $\begin{array}{l}\mathrm{t}_{\mathrm{T}}=\text { mean transit time } \\
\text { (centroid- no extrapolation) }\end{array}$ & 290 & 212 & 112 \\
\hline $\begin{array}{l}\mathrm{t}_{\mathrm{T}}=\text { mean transit time } \\
\text { (centroid - extrapolation) }\end{array}$ & $291-310$ & $213-227$ & $112-119$ \\
\hline
\end{tabular}

$\mathrm{NA}=$ not applicable. 


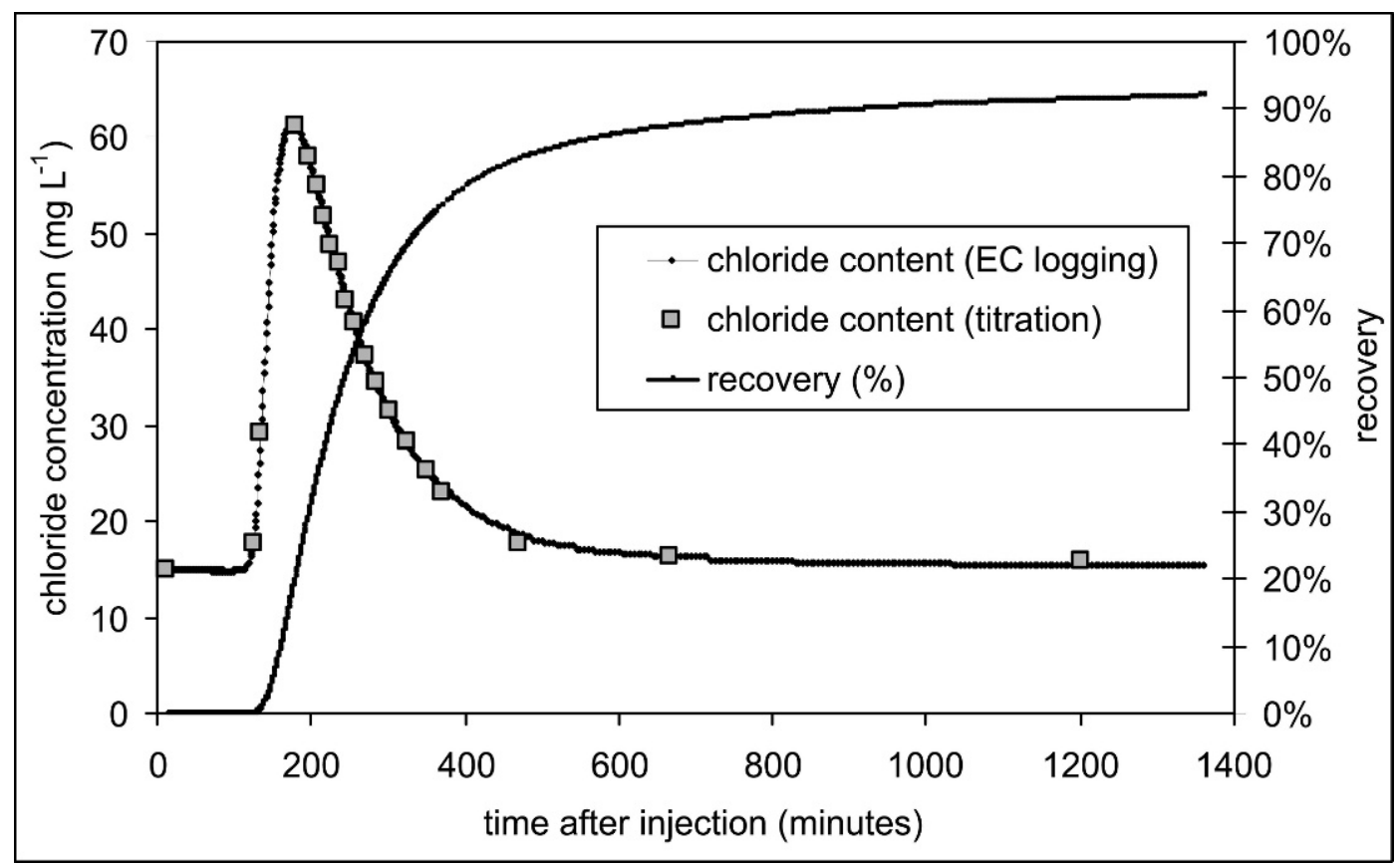

Figure 3. Chloride concentration based on argentometric titration and conductivity logging.

centroid is quite sensitive to the concentrations in the tail extending to longer times. Käss (1998) found that where breakthrough curves had very long tails (slightly increased concentration for a long time after the maximum concentration), the mean transit time is unsuitable. In such a case, the peak time may lead to better volume estimation. This is important for breakthrough curves affected by molecular diffusion into immobile water (mainly longlasting breakthrough curves, several months and more, e.g., Goldscheider et al., 2003). In such case, the mean transit time may be considerably increased by exchange with immobile water, and thus, overestimates the volume of mobile water in the conduit.

In case of common karst conduits, where the flow at the injection point $\left(Q_{1}\right)$ is often considerably smaller relative to the sampling point $\left(Q_{2}\right)$, the conduit volume $V$ is $Q_{1} \times t<$ $V<Q_{2} \times t$, where $Q$ is the stream flow rate or discharge and $t$ is the mean tracer transit time. This is applicable if bifurcation (diversion of part of water outside the conduit) can be excluded based on nearly complete tracer recovery. If all adjoining conduits are similar to the conduit into which the tracer was introduced, the volume of whole connecting conduit system will be approximately equal to $Q_{2} \times t$. On the contrary, if conduit flow is close to $Q_{1}$ for most of the underground path and only close to sampling point the conduit joins a stream with much higher discharge $\left(Q_{2}\right)$, then the volume of conduit will be approximately equal to $Q_{1} \times t$.

In case considerable diversion occurs (recovery far below $100 \%$, no loss of tracer by other processes), the conduit volume $V$ between injection and sampling point is $Q_{1} \times t \times R<V$ where $R$ is the ratio of tracer recovered at the sampling divided by tracer injected point. Diverging conduits are not counted into this volume.

In case that $Q_{1}, Q_{2}$, or both change over time, the discharge needs to be integrated over time to obtain conduit volume (Atkinson et al., 1973).

\section{Conclusions}

The isolated phreatic loop in a natural cave was used to test the reliability of tracer tests to estimate conduit volumes. The volume of a phreatic tube was measured by filling the drained phreatic loop by known discharge over known time period. Comparison of volume calculated from breakthrough curve data with the measured volume of karst conduit showed that volumes are best estimated using the mean transit time from a tracer test. In this case, the tracer test evaluation yielded conduit volumes very similar to the directly measured volume. This demonstrates that volume estimation by tracer tests may be quite precise for simple conduit geometries. On the other hand, using the first arrival or peak time in volume calculation will lead to a considerable underestimation of conduit volume compared to actuality and should be avoided except where breakthrough curves have extremely long tails.

\section{ACKNOWLEDGEMENTS}

Research was supported by institutional project No. MSM0021620855. Many thanks to Ondrej Jäger for help in the field and G.S. Springer, M. S. Field, A.L. Mayo, and a reviewer for very valuable suggestions for improving the manuscript.

Journal of Cave and Karst Studies, December 2010 •159 


\section{REFERENCES}

Atkinson, T.C., Smith, D.I., Lavis, J.J., and Whitaker, R.J., 1973, Experiments in tracing underground waters in limestones: Journal of Hydrology, v. 19, p. 323-349.

Atkinson, T.C., 1977, Diffuse flow and conduit flow in limestone terrain in the Mendip Hills, Somerset (Great Britain): Journal of Hydrology, v. 35 , p. $93-110$.

Birk, S., Liedl, R., and Sauter, M., 2004, Identification of localized recharge and conduit flow by combined analysis of hydraulic and physio-chemical spring responses (Urenbrunnen, SW Germany) Journal of Hydrology, v. 286, p. 179-193.

Bruthans, J., and Zeman, O., 2003, Factors controlling exokarst morphology and sediment transport through caves: Comparison of carbonate and salt karst: Acta Carsologica, v. 32, no. 1, p. 83-99.

Field, M.S., 2002, The QTRACER2 Program for Tracer Breakthrough Curve Analysis for Tracer Tests in Karstic Aquifers and Other Hydrologic Systems, Washington, D.C., U.S. Environmental Protection Agency, EPA/600/R-02/001, http://cfpub.epa.gov/ncea/cfm/ recordisplay.cfm?deid $=54930$.
Field, M.S., and Nash, S.G., 1997, Risk assessment methodology for karst aquifers, (1) estimating karst conduit-flow parameters: Environmental Monitoring Assessment, v. 47, p. 1-21.

Ford, D.C., and Ewers, R.O., 1978, The development of limestone cave systems in the dimensions of length and depth: Canadian Journal of Earth Sciences, v. 15, p. 1783-1798.

Goldscheider, N., Hötzl, H., Käss, W., and Ufrecht, W., 2003, Combined tracer tests in the karst aquifer of the artesian mineral springs of Stuttgart, Germany: Environmental Geology, v. 43, p. 922-929.

Goldscheider, N., Meiman, J., Pronk, M., and Smart, C., 2008, Tracer tests in karst hydrogeology and speleology: International Journal of Speleology, v. 37, no. 1, p. 27-40.

Käss, W., 1998, Tracing Technique in Geohydrology, Rotterdam, Balkema, $581 \mathrm{p}$.

Smart, C.C., 1988, Quantitative tracing of the Maligne karst system, Alberta, Canada: Journal of Hydrology, v. 98, p. 185-204.

Thrailkill, J., Sullivan, S.B., and Gouzie, D.R., 1991, Flow parameters in a shallow conduit-flow carbonate aquifer, Inner Bluegrass Karst Region, Kentucky, USA: Journal of Hydrology, v. 129, p. 87-108. 